\title{
Mining and local corruption in Africa
}

\author{
Carl Henrik Knutsen ${ }^{1}$, Andreas Kotsadam², Eivind Hammersmark Olsen ${ }^{3}$, \\ and Tore $\mathrm{Wig}^{1}$ \\ ${ }^{1}$ Department of Political Science, University of Oslo \\ ${ }^{2}$ Ragnar Frisch Centre for Economic Research \\ ${ }^{3}$ Department of Economics and ESOP, University of Oslo
}

\begin{abstract}
We investigate whether mining affects local corruption in Africa. Several crosscountry analyses report that natural resources have adverse effects on political institutions by increasing corruption, whereas other country-level studies show no evidence of such "political resource curses". These studies face well-known endogeneity and other methodological issues, and employing micro-level data would allow for drawing stronger inferences. Hence, we connect 92,762 Afrobarometer survey respondents to spatial data on 496 industrial mines. Using a difference-in-differences strategy we find that mining increases bribe payments, and this result is robust to using alternative models. Mines are initially located in less corrupt areas, but mining areas turn more corrupt after mines open. When exploring mechanisms we find that local economic activity relates differently to corruption in mining and non-mining areas, suggesting that mining income incentivizes and enables local officials already present to require more bribes.
\end{abstract}

Replication Materials: The data, code, and any additional materials required to replicate all analyses in this article are available on the American Journal of Political Science Dataverse within the Harvard Dataverse Network, at: http://dx.doi.org/XXX

Acknowledgements: We thank participants at the Tuesday Seminar at the Department of Political Science, University of Oslo, and the ESOP and OxCarre Workshop on Natural Resources, The Bergen Seminar in Development Economics, as well as Håvard Strand, Jo Thori Lind and three anonymous reviewers for very helpful comments and suggestions. We also thank Helge Hveem as well as ESOP and Kalle Moene for financial and other support, and Selemon Negash for research assistance. This project was partly funded by Research Council Norway Project number 240505 and ESOP, which is supported by the Research Council of Norway through its Centres of Excellence funding scheme, project number 179552 .

Keywords: Resource curse; Local Institutions; Corruption; Minerals; Mining; Africa 


\section{Introduction}

Several studies find that an abundance of, or dependence on, natural resources correlates with less democratic regime forms and worse governance. ${ }^{1}$ In particular, there is a correlation between natural resource measures and corruption. This may stem from natural resource revenues being easy to control and monopolize for political elites (Boix, 2003; Bueno de Mesquita and Smith, 2009), in turn reducing incentives to provide accountability and transparency. Moreover, such high-rent activities yield available funds for patronage and unofficial transactions. Expectedly, "resource-abundant countries engender a political state that is factional or predatory and distorts the economy in the pursuit of rents" (Auty, 2001, 839).

Despite this, researchers increasingly question whether the cross-country correlations undergirding such political "resource curses" reflect causal effects. This skepticism comes from increased awareness of the limitations of traditional cross-country designs for drawing inferences. For instance, Haber and Menaldo (2011) argue that the cross-country correlation between natural resource wealth and autocracy largely stems from omitted country-specific characteristics. Also the resource dependence-corruption relationship may simply reflect that corrupt countries have poorly performing industrial sectors and few other exports (e.g., Brunnschweiler and Bulte, 2008). Nevertheless, the proposed cures to these ailments, often fixed effects models on country-level panel data, increase risks of failing to identify effects that actually exist (i.e., making "Type II errors"). Exogenous macro-variables measuring natural resources are virtually non-existent, and many extant measures are fairly time-invariant within countries, thereby inflating standard errors in panel regressions.

\footnotetext{
${ }^{1}$ More specifically, natural resources refer to "point-source" non-renewable resources, notably minerals and fuels. "Resource abundance" sometimes signifies existence of rich mineral/fuel reserves, but here refers to resource extraction of high economic value. "Resource dependence" means that mineral/fuel income constitute a substantial share of total income.
} 
By studying the exact localization and opening of industrial mines and how they affect corruption locally, we provide micro-level evidence that mineral extraction, indeed, affects local-level corruption. We geographically match 92,762 respondents from four Afrobarometer waves with data on 496 mines in 33 African countries. This enables us to deal with country heterogeneity while simultaneously having sufficient variation to mitigate risks of "Type II errors". Studying both inactive mines that have yet to open and active mines, we employ a difference-in-differences strategy. Whereas we often identify negative correlations between corruption and initial mine localization - everything else equal, profit-maximizing companies prefer locating mines in less corrupt areas - we find positive correlations between corruption and active mines. Our core finding is that mining causes local corruption to increase. We also identify this effect when employing alternative strategies, such as instrumental variable models. While less strong for (more problematic) measures of corruption perceptions than for measures of bribe payments, the results on bribes to the police, in particular, are robust.

Although we cannot immediately extrapolate our conclusions to the macro-level, these results indicate a local political "resource curse". While previous studies report that mining activities have important consequences for local communities (such as increasing female labor force participation, but also conflict risk), this is the first study of its kind to investigate local institutional effects. Our study thus adds to the broader "resource curse" literature, but also to literatures on local effects of mining and on determinants of local institutions (e.g., Nunn and Wantchekon, 2011; Acemoglu, Reed and Robinson, 2014).

We first review relevant literatures. We then discuss potential mechanisms linking mining to local corruption, before addressing challenges to studying effects of natural resources on corruption. We move on to present (and evaluate) our data and design. Before concluding, we discuss the main results, report robustness tests, and explore mechanisms. 


\section{Related literature}

\section{Economic and political "resource curses"}

According to Frankel (2010), the term "resource curse" was coined by Auty (1993). Since then (and even before), numerous studies have addressed the potential economic and political consequences of natural resources production, dependence, wealth, or reserves (see, e.g., Humphreys, Sachs and Stiglitz, 2007). Although some studies indicate "resource blessings" (see, e.g., Alexeev and Conrad, 2009; Brunnschweiler, 2008) - at least given pre-existing high-quality/inclusive/producer-friendly institutions (e.g., Karl, 1997; Mehlum, Moene and Torvik, 2006; Bhattacharyya and Hodler, 2010) - the debate centers on whether or not there are "resources curses".

Regarding economic effects, the literature focuses on GDP growth. Proposed reasons for why natural resource extraction impedes growth include perpetually declining relative (resource) prices (Prebisch, 1950); large price fluctuations (Hausmann and Rigobon, 2003); incentives for prioritizing rent-seeking over productive work (Auty, 2001); lacking incentives to provide education opportunities and infrastructure (Isham et al., 2005); and, indirect negative effects through adversely affecting institutional structures and governance. Early cross-country regressions often reported negative associations between resource measures and growth (Sachs and Warner, 1995; Leite and Weidmann, 1999), although they were clearer when using export-based measures than, for instance, fuel and mineral reserve measures (e.g., Stijns, 2005). The latter indicates that different endogeneity and selection biases may drive the proposed relationship (Brunnschweiler and Bulte, 2008).

Another literature, spanning economics and political science, has studied the adverse political and institutional consequences of natural resources (e.g. Ross, 2001; Humphreys, Sachs and Stiglitz, 2007; Ross, 2012). Referring to a "Political Resource Curse" involves a (crude) generalization over how natural resource extraction affects distinct outcomes, such 
as conflict, democratization, bureaucratic quality and corruption. ${ }^{2}$ Notably, several studies consider how natural resource wealth spurs authoritarianism, suggesting that resource abundance stabilizes autocratic regimes (e.g., Cuaresma, Oberhofer and Raschky, 2011; Andersen and Aslaksen, 2013), and inhibits democratization chances (e.g., Boix, 2003; Ross, 2012). Natural resources provide a source of easily controllable wealth that regime elites may monopolize and use for co-optation or for investing in repressive capacity (e.g., Smith, 2004, 2006; Bueno de Mesquita and Smith, 2009; Cuaresma, Oberhofer and Raschky, 2011). Moreover, Ross (2001) suggests that natural resources enable "rentier states" that escape accountability by providing low taxes, relieving pressures for democratization. Despite this, Haber and Menaldo (2011) question the proposed effect on autocracy; collecting resource data back to 1800, they fail to find clear time-series evidence in most countries. Still, Andersen and Ross (2014) show that this hinges on specification choices, especially the sample time period, and Aslaksen (2010) finds indications of oil affecting regime type, using cross-country panel data. Hence, it remains unclear whether natural resource activities cause autocracy.

\section{Natural resources and corruption}

Our analysis tests how mining affects corruption, a phenomenon widely considered to deteriorate various outcomes (Holmberg, Rothstein and Nasiritousi, 2009), including investment and economic growth (Mauro, 1995). If resource abundant or dependent economies are conducive to autocracy, this may also affect governance outcomes, such as control of corruption, if such outcomes are contingent on having open and transparent democratic regimes. ${ }^{3}$

\footnotetext{
${ }^{2}$ For instance, numerous studies propose that natural resource abundance enhances civil war risk, for example by altering the incentives and capabilities of rebel groups to contest state authority (see Ross, 2004a; Humphreys, 2005). Yet, Ross (2004b) discusses how mining activities - as opposed to oil production - may not affect conflict outbreak, but prolong ongoing conflicts.

${ }^{3}$ However, the democracy-corruption literature has failed to identify a straightforward relationship; Rock (2009), for instance, finds that while post-democratization years observe
} 
Nevertheless, natural resources may also affect corruption more directly. Foreshadowing our discussion on mechanisms, we note some plausible suggestions:

First, natural resource discoveries introduce "high-rent activities" to the economy, increasing the bribes that involved economic actors can possibly pay while still reaping profits, and thereby incentivizing bureaucrats to request bribes. Furthermore, the economic costs (e.g. lost tax income) for governments of accepting corruption are lower when the economy is dominated by sectors, such as natural resource extraction, in which capital investments are less price- (and thus bribe-) sensitive (see Leite and Weidmann, 1999). In resource-dependent economies, governments therefore have weaker incentives to invest in costly monitoring and control institutions for detecting and punishing corruption. Indeed, leading government actors may themselves benefit from bribes relating to control over resource production and exports (for African examples, see Meredith, 2006). Hence, corruption should be positively related to natural resource abundance and, in particular, dependence.

Vicente (2010) employs a natural experiment on oil discovery announcements in Sao Tome and Principe, finding that oil discovery increases certain types of corruption. Despite this, and theoretical predictions mainly suggesting that natural resources increase corruption, the evidence is mixed. Ades and Di Tella (1999), Treisman (2000) and Serra (2006) do not find clear relationships (particularly on 1990s data, see Busse and Gröning, 2013). In contrast, drawing on cross-country variation from about 70 countries, Leite and Weidmann (1999) find associations between fuel production/GDP or (particularly) mineral production/GDP and corruption. Further, Busse and Gröning (2013) report effects when employing countryfixed effects models and trying to account for the endogeneity of resource-based variables. Nevertheless, the resource-corruption results from such cross-country and panel analysis vary with the specification. Bhattacharyya and Hodler (2010) find insignificant relationships once controlling for country-fixed effects. Alexeev and Conrad (2009) find that the estimated increased corruption, democracy reduces corruption over time. 
impact of oil extraction on corruption depends on correcting for income being endogenous to oil production, while consistently finding no effect of mining activities. ${ }^{4}$

\section{Using local-level data to draw inferences}

Using geo-referenced survey data (mostly from the Afrobarometer) to capture institutional characteristics, recent studies have highlighted various determinants of local institutions, such as the African slave trade (Nunn and Wantchekon, 2011; Deconinck and Verpoorten, 2013), conflict (Bellows and Miguel, 2006, 2009), social trust (Rohner, Thoenig and Zilibotti, 2013), and government trust (Linke, 2013). Our analysis contributes to this literature, but also to a rapidly growing literature on local effects of resource extraction: Maystadt et al. (2014) link local mining concessions to conflict events in DR Congo, and others have found similar effects of diamond mining on conflict (e.g., Lujala, 2009, 2010; Buhaug and Rød, 2006). Berman et al. (2014) find that mineral production strongly affects the probability and intensity of various conflict types in Africa, whereas de la Sierra (2014) finds that coltan mining, but not gold mining, spurs local rebel governance structures in DR Congo. Dube and Vargas (2013) examine income shocks and violence across Colombian municipalities, finding that positive oil price shocks (but also negative coffee price shocks) increase violence. Kotsadam and Tolonen (2013) report that mine openings make women more likely to work in the service sector and less likely in agriculture, whereas Tolonen (2014) finds that gold mine openings increase female empowerment. Finally, Goldberg, Wibbels and Mvukiyehe (2008) study "local resource curses" (although at a less local level than us) by investigating US states from 1929-2000, finding that resource dependence hampers economic development and political competitiveness.

${ }^{4}$ The effects may, however, be context-dependent, and stronger in poorer countries (Leite and Weidmann, 1999; Busse and Gröning, 2013) and countries with pre-existing "lowquality" institutions (Mehlum, Moene and Torvik, 2006; Bhattacharyya and Hodler, 2010). 


\section{Mining and corruption: potential mechanisms and threats to inferences}

\section{Why mining may increase corruption locally}

The discussed contributions to the resource-curse literature concentrate on country-level mechanisms and evidence, while we focus on the local level. One might expect also the local-level mechanisms that we highlight to matter for country-level variation in corruption (and thus inform the macro literature). ${ }^{5}$ However, even if they do not, an effect of mines on local-level corruption is significant in itself, given the many people living in mining areas and the substantial importance of our estimated local-level effects.

In any case, the literature suggests that both an abundance of and dependence on natural resources may deteriorate governance. But, which features related to mining increase local corruption more specifically, and why? Indeed, potential mechanisms could contribute to mining reducing local corruption. For instance, large-scale operations might make it profitable for firms to invest in local public goods, including law enforcement, to reduce production and transaction costs (see, e.g., Esteves, 2008). By doing so, mining firms could

${ }^{5}$ This could be justified theoretically, for example, in a simple model assuming that mining affects national corruption through both local and national channels. For the national, mining induces corruption through mechanisms such as increasing the total national-level rents appropriable for corruption payments (as emphasized in the macro literature). Further, mines have local-level effects through the mechanisms discussed below. The local-level effects induced by one specific mine will increase corruption in a (positive, though small) share of the national territory; at one extreme (mines in every locality) the entire territory is affected by such local-level mechanisms, and at the other (no mines nationally) no part of the territory is. Thus, the aggregate effect of an additional mine on corruption is a function of the nationallevel component and the local-level component (weighted by the share of locations with a mine). 
"crowd out" pre-existing (low-quality) local institutions, potentially reducing corruption.

Nonetheless, the sum of arguments below suggests contrary effects. We address two types of mechanisms linking mining to local corruption; one focusing on supply of funds available for corruption, and another on demand for bribes generated by inflows of corrupt officials. Both come in two versions - a "general growth version" (assuming mining income is equivalent to income from other sources), and a "mining-specific version" highlighting that resource extraction has more corruption-generating potential than other activities. This yields four explanations, each with distinct testable implications.

\section{General growth explanations}

The general growth-supply explanation highlights that mine openings boost local growth, increasing incentives and opportunities of (already present) local officials to successfully require bribes. While the literature review suggested an unclear long-term net effect on income, mining expectedly boosts short-term growth, and especially locally. Besides growth coming directly from mineral production, mining increases demand for services by mine workers and for local inputs to production. Mine openings thus increase income for local businesses, and put upwards pressures on wages through generating labor demand. This allows officials, such as police officers, to request more bribes, anticipating that locals can now better afford to pay them. Indeed, mining operations are relatively large industrial activities, and could generate stronger such effects than modest growth in other sectors, particularly in less populated or poor communities. In essence, large-scale mining could magnify whatever effect growth has on corruption. Yet we remain skeptical. First, mining income is likely not equivalent to other income concerning corruption opportunities (see below). Second, the link between income per se and corruption is questionable; local growth might reduce corruption through various channels. For example, growth provides more resources for building wellfunctioning institutions and paying salaries to local officials (see, e.g., Van Rijkgehem and Weder, 2001). Nonetheless, if this explanation is valid, the observable implications are that 
a) mine openings are positively related to local growth, and b) local income (in mining and non-mining areas) is positively related to local corruption. Further, controlling for local economic activity should attenuate the relationship between mine openings and corruption.

Whereas the above mechanism predicts increased corruption even if mine openings do not attract new officials - those present may simply take more bribes - the number of (corrupt) officials locally could increase. Accordingly, the second general growth explanation highlights that mining (and other income-generating activities) increases local demand for corruption by boosting the presence of officials such as tax collectors or safety-regulations inspectors, but also police officers (for which we have abundant, relevant data). A mine opening, and related increases in local economic activity, could tempt corrupt officials to spend more time nearby, entailing more interactions with locals. Also, corrupt officials would, given the opportunities for successfully demanding bribes, have stronger incentives to apply for jobs in high-activity districts, including mining districts. If true, the observable implications are that a) mine openings increase the observed presence of police, and b) economic activity correlates positively with police presence locally.

\section{Mining-specific explanations}

While the general growth explanations connect mining with corruption through effects on growth as such, mining may engender more corruption than other activities. One potential corruption-generating feature is the industry's opacity concerning quantities and revenues. Extractive operations are often structured such that firms can effectively conceal revenue (especially when cooperating with officials inspecting production and revenue streams). Further, if corruption is rife in the mining sector, local mining establishments could even engender local "cultures of corruption" (e.g., Fisman and Miguel, 2006)—making bribe requests and payments socially more acceptable - potentially inducing increased local corruption also in non-mining sectors.

Second, resource production is a high-rent activity with considerable profit margins. 
Production is also geographically fixed; minerals in the ground are immobile, and when mines are set up it is expensive to move equipment. Therefore, mining is less sensitive to different variable costs, including requested bribe payments. Related, the bribery "market" does not move. Potential bribe-takers can infer the profitable spots to "set up shop", since they know the invariant location of places with high economic activity (both mining- and related activities). Combined with high rents in mining - and likely in other sectors locally, where prices are driven up by demand from mining activity - this creates a valuable opportunity for, e.g., police officers with relatively low wages (for an illustration from Zimbabwe, see Human Rights Watch, 2009). ${ }^{6}$ These characteristics suggest that natural resource abundance positively affects local corruption even if other income-generating activities have zero-, or even negative effects, and natural resource dependence should be clearly conducive to local corruption.

These insights can be incorporated with the supply and demand explanations, thus generating two mining-specific explanations. If a mining-specific supply mechanism operates, mining-induced economic activity should increase corruption more than other activities. The observable implication is an interaction effect between mining activities and local income on local corruption. The mining-specific formulation of the demand mechanism predicts larger inflows of corrupt officials in areas with mining-induced growth. Consequentially, observable implications are that a) local income correlates more strongly with police presence (for which relevant data exists) in mining- than non-mining areas, and b) the link between police presence and police bribes is stronger positive in mining areas. We test these expectations below, but first discuss some fundamental methodological challenges.

\footnotetext{
${ }^{6}$ Correspondingly, if business is more cost-sensitive in non-mining areas, excessive bribetaking more easily deters activity, effectively limiting bribe requests.
} 


\section{Endogenous resource extraction}

The extant evidence for economic and political "resource curses" is more mixed than what early cross-country studies (Sachs and Warner, 1995; Ross, 2001) indicated. The results on corruption are also mixed, pivoting on two issues; country heterogeneity and endogenous resource measures. Hence, the causal direction of the relationship, and in what contexts a potential effect operates, is uncertain.

We investigate these questions using a different design and data than studies dealing with the above-noted concerns through country-fixed effects and exogenous national-level variation in natural resources. These studies necessarily draw on limited information. Truly exogenous country-level measures are scarce, and most have limited within-country temporal variation. Brunnschweiler and Bulte (2008) propose employing "subsoil assets", estimated from World Bank data. However, such measures are often imputed, extra-/interpolated, or even based on multiples of yearly production. And, even if we could combine within-country variation with exogenous measures on subsoil reserves, it is unclear when the mere presence of resources expectedly starts affecting corruption. Consequentially, such analysis could yield false null-findings, particularly for short time series (as for most corruption indicators) and slow-moving variables (Beck and Katz, 2001). Drawing on rich local-level variation in mining and corruption, our setup alleviates these issues.

Studies using national-level data may also fail to identify clear effects on corruption because extraction is endogenous: Much research highlights how location and scale of economic activity is affected by the surrounding institutional framework. Whereas certain institutions reduce production and transaction costs, others increase them (e.g., North, 1990). Corruption, in particular, should impose additional costs on firms (Svensson, 2005). At best-when centralized and transparent—-bribes work like taxes, and pervasive, decentralized corruption generates exceedingly high costs (Shleifer and Vishny, 1993). Thus, corruption reduces, for 
example, inward foreign investments (Blonigen, 2005).

Although supply curves for natural resources production are less elastic - and thus less sensitive to expected bribes - than other activities, corruption levels might make the difference between investing and not for some extraction projects. We can only speculate, but it seems unlikely that the expensive tar sand and shale-gas gas extraction in Canada and the US, respectively, would be initiated in countries with the corruption levels of Afghanistan or DR Congo. Corruption increases business costs also for mining, and while several resource economies are corrupt, the resource revenues of Afghanistan or DR Congo would probably increase, ceteris paribus, if corruption went down. When estimating how mining, in turn, affects corruption, we should account for such "selection effects". 7

Given the mixed extant results and the endogeneity issues, we do not yet know whether natural resource extraction increases corruption. We therefore shift focus from macro to micro data, and exploit local-level variation. We trace differences in corruption between areas with mines that have yet to open activity and areas with active mines, following the strategy in Kotsadam and Tolonen (2013). This accounts for selection of mining activities into areas with particular characteristics - firms, ceteris paribus, expectedly prefer opening mines in less corrupt areas - relieving a critical source of endogeneity. If the "resource curse" hypothesis on corruption holds, corruption should be higher in areas with active mines than where mines are still inactive.

One can, of course, never guarantee that these areas are perfectly comparable: In our sample, inactive mines are typically younger (opened 2001-2012). If companies first locate where corruption is low, active mines would have had lower initial corruption than inactive.

\footnotetext{
${ }^{7}$ There may also be other endogeneity biases: Mine construction permits may be easier to obtain where bribes can speed up the bureaucracy. Alternatively, corruption increases the number of permits required and slows down mine building. Also, corruption may affect the provision of mining concessions.
} 
Thus, our results - indicating that mining increases corruption - may be downward biased. Corruption in extractive industries has recently received increasing attention, as evidenced by the Extractive Industries Transparency Initiative (EITI) (see, e.g., Corrigan, 2014). Possibly, companies could follow different location strategies today-systematically selecting less corrupt areas - than in the 1980s. Comparing active and inactive mines of similar age alleviates such problems, and our results hold when only studying mines opening within 10 years of the relevant Afrobarometer survey. We also conduct analyses with mine-fixed effects to (only) compare the same area before and after mine opening.

Another potential endogeneity issue is that timing of mine openings potentially relate to corruption, or firms' expectations of corruption. Since corruption is costly, firms might hesitate to open mines when anticipating or observing spikes in local corruption, awaiting a corruption-mitigating reform or change of local government. If so, any corruption-enhancing effect of mine opening may be under-estimated. While this is certainly possible, we believe openings conditional on location (if anticipated local corruption enters business calculations, it should also affect location decisions) to be largely determined by exogenous forces such as expected world market prices. Nonetheless, we account for this possibility by exploiting such exogenous factors in instrumental variable models.

Yet we caution against too readily generalizing our results to the national level. First, local corruption is not necessarily driven by similar factors as national corruption (we suggested above that some mechanisms apply only/more strongly locally). Further, the scale of our measure differs (opening of single mines versus country-wide resource measures). Also, since we disregard general equilibrium effects, local effects are not automatically transferable to the macroeconomy; increased corruption near active mines might, for instance, correlate with decreases elsewhere if corrupt officials leave for mining communities. Nevertheless, our results, at least, document a "local political resource curse", which is significant in itself. 


\section{Data and model specification}

\section{Data sources}

We use a novel, longitudinal dataset on large-scale mines, The Raw Materials Database (RMD) from SNL Metals \& Mining (2014). This contains information on past and current industrial mines, often with foreign (mainly Canadian, Australian or British in our sample) or government ownership, and future mines with industrial-scale development potential (see Appendix Section A.1 for minerals included). It excludes small-scale mines and informal, artisanal or illegal mines. The external validity of our (main) results therefore pertains to large-scale industrial mining. The data is geocoded with point coordinates, and mine production data exist annually for 1975 and 1984-2013.

Measuring corruption is difficult (e.g., Svensson, 2005), and no available measure is without problems. Therefore, we test different measures, reporting results from two questions on perceptions of local corruption and two on respondents' reporting of actually paid bribes from Afrobarometer Data (N.d.). These four are selected since they have data across all Afrobarometer waves, but we report strong results for other Afrobarometer bribe-payment questions (e.g., to tax officials) with less extensive coverage in the Appendix.

Corruption perception measures are, in general, problematic (e.g., Olken, 2009). These measures might work better when pertaining to local-level corruption closer to people's everyday lives than for national-level corruption; respondents' replies more often draw on firsthand knowledge. But, even such perceptions may be biased. If respondents, for example, consider very high corruption levels as normal, they may perceive highly corrupt environments as less corrupt. Asking directly about behavior mitigates such concerns. Thus, we mainly rely on Afrobarometer items on bribe payments. ${ }^{8}$

\footnotetext{
${ }^{8}$ However, not all relevant bribes are captured; African mines are largely foreign- or stateowned, and bribes paid by mine owners are thus often missed when surveying the local
} 
We mainly employ two questions on bribe experience: Respondents are asked if they have paid a bribe for "avoiding problems with the police" or "a document or permit" and can answer "Never", "Once or Twice", "A Few Times", "Often", or "No experience with this in past year". The permit question may yield less precise results, since requesting permits is more relevant for sub-sets of respondents (e.g., business owners) and is sometimes done in anticipation of (i.e., before) mine openings (attenuating difference-in-differences estimates). Nonetheless, we create two main dependent variables (bribe to police and bribe for permit) by coding those that have never bribed or not bribed the last year as 0 . The other categories range from 1 (Once or twice) to 3 (Often). We complement this with two perception measures. Respondents are asked how many of their local government councilors and within the police they think are corrupt, and can answer "None", "Some of them", "Most of them", "All of them" — these variables range from 0 (None) to 3 (All). Our corruption measures are, strictly speaking, ordinal. Importantly, while our baselines are easy-to-interpret linear models, results are robust to employing ordinal logit or to recoding the indices as dummy variables.

There are sampling issues with both the Afrobarometer and RMD data. For example, Francophone countries are under-represented in the Afrobarometer, which also excludes countries with significant mining activity. Readers should note this before generalizing our results to the entire continent. Still, this selection could bias results against our hypothesis; significant excluded mining countries, such as Angola and DR Congo, have worse institutions and governance outcomes than most included countries, and various studies (some reviewed above) have linked mining to deterioration in local governance outcomes in these countries (particularly DR Congo). Since RMD excludes artisanal mining (i.e., small-scale subsistence mining), our inferences apply to industrial mining. However, we conduct tests using other datasets on alluvial diamonds, a wider set of small-scale and large mines, and onshore oil population. 
(Appendix Section A.2). We find fairly strong relationships with local corruption also for these measures.

\section{Connecting mines with survey respondents, and our samples}

The baseline analysis draws on four Afrobarometer Waves (2-5) conducted in 33 countries (Appendix Figures A.1-A.2 provide maps of mine- and survey-cluster locations). We link mining to Afrobarometer data based on spatial proximity, employing point coordinates (GPS) of the Afrobarometer clusters - i.e., one or several geographically close villages or urban neighborhood - to match individuals to mines (with accurate GPS coordinates). The RMD data identifies 604 African industrial mines, and our 33-country sample allows matching 496 mines to survey respondents. From a cluster center point we measure distance to mines and register if $\geq 1$ mine exists within 50 kilometers $(\mathrm{km})$. The indicator variable $A c$ tive captures whether $\geq 1$ active mine lies within this distance. If not, we code individuals as Inactive if $\geq 1$ future mine will be opened in the area. All other individuals are coded as living in non-mining areas.

We geolocated respondents using geographical information from the Afrobarometer. Wherever possible, we use official enumeration area (EA) boundaries. This is the Afrobarometer's primary sampling unit (PSU) and the most precise geographical unit for locating respondents (although precision depends on EA size, which varies between areas of different population densities). Currently, EA boundaries are available for South Africa and several regions of Sierra Leone. Other observations either lack official EA codes, or we could not obtain them even after contacting different agencies. Thus, we placed respondents without EA information on the centroid coordinate of reported town, village or neighborhood of residence using Google Maps. We discard respondents that could only be located at the district or region level.

This respondent-to-mine matching algorithm, which turns out surprisingly effective, was evaluated using a benchmark from South Africa: We compared the precision of our Google 
maps-based coordinates with those in Nunn and Wantchekon (2011) by measuring distance between estimated locations and true locations using EA information from the 2001 South African census. The average distance from the EA, i.e. the geolocation error, is $124 \mathrm{~km}$ for Nunn and Wantchekon (2011) and $13 \mathrm{~km}$ with our coordinates. The 75 percentile distances are $100 \mathrm{~km}$ and $9 \mathrm{~km}$, respectively. ${ }^{9}$ For Afrobarometer Wave 4, Deconinck and Verpoorten (2013) have more precise coordinates (75 percentile distance=17km) than Nunn and Wanthcekon for Wave 3 , but less precise than us $(75$ percentile distance $=4.9 \mathrm{~km}) .{ }^{10}$ Our geocoding precision is fairly similar for Waves 2 and 5, and altogether we located $97 \%(11,647 / 11,999)$ of South African respondents at the EA level.

We draw on Nunn and Wantchekon (2011) for Wave 3 and Deconinck and Verpoorten (2013) for Wave 4 to localize additional individuals where our strategy did not yield results. ${ }^{11}$ However, our results are quite similar when dropping these additional respondents.

In our baseline sample respondents live, on average, $208 \mathrm{~km}$ from a mine (Appendix Table A.2 provides descriptive statistics). $15.7 \%$ (of 92,762) respondents live within $50 \mathrm{~km}$ of an active mine, and $1.4 \%$ within $50 \mathrm{~km}$ of an inactive (but no active) mine. 604 mines have information on location and opening year in Africa, whereof 496 are matched to clusters, and 426 are within $50 \mathrm{~km}$ of $\geq 1$ cluster.

\footnotetext{
${ }^{9}$ Results are similar when including only EAs smaller than $40 \mathrm{~km}^{2}$.

${ }^{10}$ Deconinck and Verpoorten (2013) use centroids of districts or regions where towns cannot be geocoded, so the lack of precision is somewhat mechanic, and not necessarily due to geocoding errors.

${ }^{11}$ The data from Nunn and Wantchekon (2011) are available at http:// scholar.harvard.edu/nunn/pages/data-0. We thank Koen Deconinck and Marijke Verpoorten for sharing geocodes for Wave 4, and the Afrobarometer for providing geographical information.
} 


\section{Empirical Strategy}

Our estimation relies on a spatial-temporal strategy resembling that in Kotsadam and Tolonen (2013). Assuming that corruption is affected within a cut-off distance, we consider three groups, namely individuals living (A) within $50 \mathrm{~km}$ from $\geq 1$ active mine, (B) within $50 \mathrm{~km}$ from an inactive (but no active) mine that has not started producing in the survey year, and (C) more than $50 \mathrm{~km}$ from any mine. ${ }^{12}$ The baseline regression equation is:

$$
Y_{i v t}=\beta_{1} \cdot \text { active }+\beta_{2} \cdot \text { inactive }+\alpha_{c}+g_{t}+\lambda \cdot \mathbf{X}_{\mathbf{i}}+\varepsilon_{i v t},
$$

where the corruption-measure outcome $Y$ for an individual $i$, cluster $v$, and year $t$ is regressed on active and inactive. The regressions include country- $\left(\alpha_{c}\right)$ and year-fixed $\left(g_{t}\right)$ effects, and a vector $\left(X_{i}\right)$ of individual-level controls (living in urban area, age, age ${ }^{2}$, education, and gender; from Afrobarometer). Standard errors are clustered at the geographical clusters (EA, town or neighborhood) to account for correlated errors. Our results are, however, retained for alternative control sets and alternative clustering options.

Interpreting the coefficient for active in isolation assumes that mine location is uncorrelated with institutional characteristics before production starts. This is, as discussed above, a strong assumption because corruption levels - and other factors possibly correlating with corruption, such as population density and infrastructure accessibility - likely influence mining companies' investment decisions. Companies may, ceteris paribus, be less inclined to invest in corrupt areas. Including inactive allows comparing areas before a mine opens with areas after a mine opens, and not only areas close to and far from mines. ${ }^{13}$ We therefore

\footnotetext{
${ }^{12}$ Mines for which production is zero or production figures are not reported in some intermediate year, but where production reportedly resumes thereafter, are coded active. Areas with previously operating mines where activity is suspended for longer periods are excluded.

${ }^{13}$ Since active codes mining areas with active mines as 1 and inactive codes areas with yet unopened mines - and no active mines - as 1, we can think of this as a set of dummies where
} 
provide test results for the difference between active and inactive $\left(\beta_{1}-\beta_{2}\right)$, obtaining a difference-in-differences measure that controls for unobservable time-invariant characteristics influencing selection into being a mining area. ${ }^{14}$

Our 50km cut-off distance is, admittedly, somewhat agnostic, but seems appropriate considering practical commuting distances in the African context and balances potential attenuation biases that may ensue from too short and too long distances. Smaller cut-off distances quickly decrease the (limited) sample of inactive individuals, making it harder to identify effects. They also inflate geocoding errors relative to the cut-off distance, increasing the probability of defining non-treated individuals as treated when, and vice versa. A too large cut-off, however, includes too many control individuals in the treatment group, also pulling down $\beta_{1}-\beta_{2}$.

Our first strategy thus essentially controls for differences between mining and non-mining areas such as different geological properties, which may have shaped institutions prior to mining (Nunn and Puga, 2012). We also employ mine-fixed effects $\left(\delta_{m}\right)$ to isolate changes in corruption over time within specific areas. While this identification strategy has stronger the reference category is non-mining areas. Hence, the inactive coefficient, interpreted in isolation, shows the difference in corruption between an inactive mining area and a non-mining area. It is logically possible that a negative inactive coefficient reflects a negative causal effect of (simply having) mineral endowments on corruption. Still, we find this implausible, absent any clear theoretical argument for such an effect. Following the discussion on endogenous resource extraction, the most plausible interpretation is that such a coefficient reflects companies' selective placement of mines in areas with lower corruption, ceteris paribus.

${ }^{14}$ Equation (1) is not a standard diff-in-diff, but can be interpreted as such. We are comparing both post-treatment individuals (active) and pre-treatment individuals (inactive) with all other control individuals (non-mining area) within the same country and interview year (due to the fixed effects). One single control individual will thus often enter the comparison group for both pre- and post-treatment individuals - any assignment to either pre- or post-treatment would be arbitrary. 
internal validity, it greatly limits the sample and information, requiring observations in different Afrobarometer waves within the same mining area before and after a mine opens. In our mine-fixed effects models, $\beta_{1}$ is directly interpretable as the effect of opening a mine:

$$
Y_{i m t}=\beta_{1} \cdot \text { active }+\delta_{m}+\alpha_{c}+g_{t}+\lambda \cdot \mathbf{X}_{\mathbf{i}}+\varepsilon_{i v t}
$$

\section{Results}

\section{Main results}

Table 1 reports our baseline models. The results indicate that active mining areas are associated with more bribe payments; active is significant at $1 \%$ for police bribes (Model 1), and at 5\% for permit bribes (Model 2). The estimates are substantial, particularly for police bribes with the coefficient (0.024) constituting $>\frac{1}{10}$ of the police bribe index' mean $(0.23)$. Still, our discussion on endogenous localization of mines suggested that active underestimates the effect of mining on corruption, since companies have incentives to invest in less corrupt areas. While only the police bribe result is significant (1\%), inactive is negatively signed in both models, indicating that mines are located in areas with lower corruption.

Importantly, we corroborate the hypothesis that mining increases corruption. Employing the discussed difference-in-differences strategy, $\left(\beta_{1}-\beta_{2}\right)$ is positively signed. The police bribe result is significant at $1 \%$, whereas $p=0.086$ for permit bribes. Indeed, the former result holds up to the Bonferroni correction, as $p<0.0125$ ( $\mathrm{p}=0.05 / 4$ tests). Furthermore, the point estimate for Model 1 predicts that a mine opening increases the police bribe index

with 0.074 , about $\frac{1}{3}$ of its sample mean. When re-estimating the model, but dichotomizing the police bribe index (Appendix Table A.16), a back-of-the-envelope calculation drawing on spatialized population data (see Balk et al., 2006) suggests that about 18 million Africans lived within $50 \mathrm{~km}$ of inactive mines in 2000 , of which an estimated additional seven hundred thousand have paid police bribes annually resulting from post-2001 mine openings. 
Table 1: Effects of mine openings on corruption. Baseline models.

\begin{tabular}{|c|c|c|c|c|}
\hline & \multicolumn{2}{|c|}{ Bribes } & \multicolumn{2}{|c|}{ Perceptions of Corruption } \\
\hline & $\begin{array}{c}(1) \\
\text { Police }\end{array}$ & $\begin{array}{c}(2) \\
\text { Permit }\end{array}$ & $\begin{array}{c}(3) \\
\text { Local Councilors }\end{array}$ & $\begin{array}{c}(4) \\
\text { Police }\end{array}$ \\
\hline Active $50 \mathrm{~km}$ & $\begin{array}{c}0.024 \\
(3.036)\end{array}$ & $\begin{array}{l}0.015 \\
(2.075)\end{array}$ & $\begin{array}{c}0.026 \\
(1.811)\end{array}$ & $\begin{array}{c}0.069 \\
(5.213)\end{array}$ \\
\hline Inactive $50 \mathrm{~km}$ & $\begin{array}{l}-0.050 \\
(-3.778)\end{array}$ & $\begin{array}{l}-0.024 \\
(-1.073)\end{array}$ & $\begin{array}{l}-0.089 \\
(-1.733)\end{array}$ & $\begin{array}{c}0.063 \\
(1.901)\end{array}$ \\
\hline Difference in differences & 0.074 & 0.039 & 0.115 & 0.006 \\
\hline F-test: active-inactive $=0$ & 28.315 & 2.950 & 4.813 & 0.033 \\
\hline p-value, F-test & 0.000 & 0.086 & 0.028 & 0.855 \\
\hline Mean dep. var & 0.225 & 0.229 & 1.307 & 1.609 \\
\hline R-squared & 0.077 & 0.064 & 0.096 & 0.101 \\
\hline No. of observations & 92,762 & 92,863 & 63,481 & 83,860 \\
\hline
\end{tabular}

Notes: T-statistics in parentheses, and errors clustered at EA/town level. "Diff-in-diff" tests are presented in bottom rows. All regressions control for country- and year-fixed effects, urban area, age, age $^{2}$, gender and education. The sample includes Afrobarometer Waves 2, 3, 4 and 5, and 2.5 for South Africa. Geocodes are from our Google-maps matching algorithm. When missing, data are complemented with geocodes from Nunn and Wantchekon (2011) and Deconinck and Verpoorten (2013) for Waves 3 and 4, respectively. Geocoding in South Africa (and some observations in Sierra Leone) is based on census enumeration areas. Areas with only suspended mines within $50 \mathrm{~km}$ are excluded.

As discussed, perception measures are more problematic than items asking about actual bribe payments. Yet, also for perceived local councilor- (Model 3) and police corruption (Model 4), active remains positive with t-values of 1.8 and 5.2, respectively. The results for inactive are mixed. Model 3 reports a negative coefficient, whereas inactive is positive in Model 4. Most importantly, the point estimates for $\beta_{1}-\beta_{2}$ are positive also for the perception measures, although only significant (5\%) for local councilors. Thus, while our results are not robust across measures, they still suggest that mining increases corruption locally.

We conducted placebo tests using Afrobarometer indicators tapping perceptions of nationallevel corruption (Appendix Section A.3). Since national corruption is identical for all citizens in a country, this should not correlate with $\beta_{1}-\beta_{2}$. A correlation could suggest that more subjective-psychological factors drive (also) our core results. However, mine openings are clearly not associated with perceived national corruption. 


\section{Robustness tests}

The main result - mining activities increase corruption - is robust (Appendix Sections A.4-A.9 provides tables and extended discussions). First, the bribe-payment result seems generalizable to other officials than police officers, as theoretically expected. Some Afrobarometer waves include bribe payment questions pertaining to various officials (e.g., tax officials), and results are generally strong despite less extensive coverage.

Further, the baseline results are retained when clustering errors on the closest mine, when only including mines opening within 10 years from when respondents are surveyed, and for different covariate sets. When comparing models without controls to our baseline, the difference-in-differences estimates change very little while R-squared drops substantially. Hence, bias stemming from potential unobserved confounders must be extremely large relative to the estimated effects for our results to stem from confounding (see, e.g., Oster, 2013). We tested models using EA as unit-averaging respondents' corruption-item scores within the EA - and the results are retained. We also investigate sensitivity to functional form assumptions, testing dummy variables or the original indices in ordered logit models, with little difference in results.

To check whether differences in scale influence our aggregate results, we separate highproduction- from low-production mines (relatively, among the large-scale industrial mines with RMD data). We use RMD production data and estimate production values using worldmarket prices, and identify clear effects for both high- and low-production mines. Further, opening yet another mine in areas rich with mining activity might not have an equally strong effect (corruption should already be high) as opening the first. We therefore, for example, ran models conditioning on (log/linear) number of already active mines. While we do find indications that opening more mines further increases corruption, what mainly matters for corruption is going from not being to being an active mining area. 
Table 2: Effects of mine openings on corruption. Mine-fixed effects

\begin{tabular}{|c|c|c|c|c|}
\hline & \multicolumn{2}{|c|}{ Bribes } & \multicolumn{2}{|c|}{ Perceptions of Corruption } \\
\hline & $\begin{array}{c}(1) \\
\text { Police }\end{array}$ & $\begin{array}{c}(2) \\
\text { Permit }\end{array}$ & $\begin{array}{c}(3) \\
\text { Local Councilors }\end{array}$ & $\begin{array}{c}(4) \\
\text { Police }\end{array}$ \\
\hline Active $50 \mathrm{~km}$ & $\begin{array}{c}0.088 \\
(3.114)\end{array}$ & $\begin{array}{l}-0.012 \\
(-0.329)\end{array}$ & $\begin{array}{c}0.011 \\
(0.101)\end{array}$ & $\begin{array}{l}-0.026 \\
(-0.391)\end{array}$ \\
\hline Mean dep. var & 0.172 & 0.175 & 1.317 & 1.536 \\
\hline R-squared & 0.014 & 0.012 & 0.025 & 0.021 \\
\hline No. of observations & 15,813 & 15,820 & 9,510 & 14,592 \\
\hline
\end{tabular}

While our Google-maps based algorithm seems fairly accurate, precision could vary across contexts. Our results could be attenuated if individuals living close to mines are measured as living in non-mining areas. ${ }^{15}$ We therefore employ a sub-sample where we know that errors are minimized: For South Africa, we have five Afrobarometer survey waves (> 10000 individuals), numerous mines, and precise geocoding with official enumeration areas. Our results are retained in this sub-sample (Appendix Section A.7). ${ }^{16}$

Table 2 presents mine-fixed effects results. This conservative specification has the advantage of only comparing the exact same areas before and after mine opening. The disadvantage is that we only have Afrobarometer observations before and after mine openings for a few locations, making this a demanding test. Nonetheless, mine openings increase reported police bribe payments $(p<0.01)$. This is a very strong result-again surviving the Bonferroni correction - given the data limitations.

\footnotetext{
${ }^{15}$ Unsurprisingly, results are weaker for a $25 \mathrm{~km}$ distance-from-mine threshold for active/inactive: The number of active and inactive observations then fall dramatically. There is likely also strong attenuation bias; even for South Africa, and with our relatively precise geolocation strategy, the average location error is $13 \mathrm{~km}$.

${ }^{16}$ In Appendix Section A.8 we investigate result consistency across other sub-samples; when excluding South Africa, more/less corrupt countries, democracies/autocracies, and richer/poorer countries. The results are qualitatively stable across sub-samples.
} 
Finally, we discussed that the event of opening a mine might also be endogenous. To check whether this drives our results, we employ instrumental variable models to obtain consistent estimates of the effect of mine activity. Identifying strong instruments is challenging, and exclusion restriction concerns are hard to avoid. Still, we explored 2SLS models using different variables correlated with mine activity, and where the exclusion restriction is not obviously violated (at least when conditioned on covariates). Detailed discussions are provided in Appendix Section A.9, but, briefly, we tested models employing presence or number of mines in the wider (outside) region, and variables capturing production and export conditions for particular minerals in a given year, as instruments. These are all strong instruments, and the second-stage results corroborate the above-reported effect.

In sum, our results indicate that mining increases local corruption. ${ }^{17}$ Although results are less robust for perception-based measures, the relationship is particularly strong for police bribes.

\section{Exploring mechanisms}

In the theoretical discussion we presented four mechanisms tying mining to local corruption (income-growth and presence-of-officials, both specified according to whether resource extraction is considered similar or more conducive to corruption than other activities). We assess these four mechanisms, focusing on police bribes for which we identified a very robust net relationship. ${ }^{18}$

First, we explore the proposed (general supply) mechanism that mining enhances corrup-

\footnotetext{
${ }^{17}$ In contrast, we find more mixed evidence on mine openings and national-level corruption (Appendix Section A.11).

${ }^{18}$ The interpretation of some results in this section follow standard mediation logic (e.g., a reduced coefficient on $\mathrm{X}$ when $\mathrm{M}$ is added to a regression on $\mathrm{Y}$ suggests that part of the effect of $\mathrm{X}$ on $\mathrm{Y}$ is mediated through $\mathrm{M}$ ). We note that these inferences are more fragile than those on the net effects, as mediation analysis rests on a set of (additional) strong assumptions (such as the model including all relevant mediators correlated with M; see Imai et al., 2011).
} 
Table 3: Using nighttime lights to explore mechanisms

\begin{tabular}{lcccc}
\hline & $\begin{array}{c}(1) \\
\text { Median light }\end{array}$ & $\begin{array}{c}(2) \\
\text { Bribe to Police }\end{array}$ & $\begin{array}{c}(3) \\
\text { Bribe to Police }\end{array}$ & $\begin{array}{c}(4) \\
\text { Bribe to Police }\end{array}$ \\
\hline Active $50 \mathrm{~km}$ & 2.7265 & & 0.0590 & 0.0454 \\
& $(14.208)$ & & $(6.554)$ & $(4.552)$ \\
Inactive $50 \mathrm{~km}$ & 0.6483 & & -0.0429 & \\
& $(3.487)$ & & $(-3.372)$ & -0.0071 \\
Median light & & 0.0008 & -0.0003 & $(-4.001)$ \\
& & $(0.860)$ & $(-0.269)$ & 0.0078 \\
Median light $\times$ Active 50 km & & & & \\
& 2.078 & & 0.102 & \\
\hline Difference in differences & 59.570 & & 54.853 & $0.073)$ \\
F-test: active-inactive=0 & 0.000 & & 0.000 & 0.200 \\
p-value, F-test & 1.987 & 0.200 & 0.200 & 6,857 \\
Mean dep. var & 0.318 & 0.203 & 0.209 & \\
R-squared & 6,858 & 6,857 & 6,857 & \\
No. of observations & & & & \\
\hline
\end{tabular}

Notes: T-statistics in parentheses, and errors clustered at EA/town level. All regressions control for country- and year-fixed effects, urban area, age, age ${ }^{2}$, female and education. See Table 1 for specifics on operationalizations.

tion primarily through local growth. This requires a decent proxy for local income, measured for similar units over time. We thus use satellite-retrieved images on nighttime light emissions. Several studies report that nighttime light corresponds well with economic activity (e.g., Henderson, Storeygard and Weil, 2012); Appendix Section A.10 discusses these data and measures. To recapitulate, this first mechanism implies that A) mine openings are followed by increased local economic activity, and B) increased activity, in general, is associated with more bribes. We find strong evidence for A). The point estimate for $\beta_{1}-\beta_{2}$ (Model 1 , Table 3) suggests that mine openings increase median light intensity by 2.2 points (> 100 percent increase from mean), with $p<0.01$. In contrast, $\mathrm{B}$ ) is not supported, as the light coefficient on police bribes is positive but small, and $t=1.0$ (Model 2). Further, controlling for economic activity does not change the effect of mine openings on bribes (Model 3). Hence, mining does not increase corruption merely as a by-product of a (more general) increase in economic activity.

Nonetheless, more nuanced expectations flow from the mining-specific version: Although 
economic activity, in general, does not increase corruption, activity associated with natural resource extraction might. To investigate this (mining-specific supply) mechanism we estimate Model 4, which interacts being an active mining area with light-emissions. The interaction term is highly significant $(t=4.3)$, suggesting that economic activity is systematically more conducive to corruption in mining areas than elsewhere. Higher economic activity corresponds with fewer bribe payments in non-mining areas $(t=-4.2)$. We noted that theoretically economic growth, as such, could expectedly increase local corruption through some channels and reduce it through others; this result suggests that the latter dominate. However, extensive corruption might also reduce growth, which would depress the correlation. Indeed, this could attenuate the correlation also in mining areas, and explain why the positive growth-corruption correlation here is insignificant. We leave investigations of this for future research, but note that growth displays a systematically different relationship with corruption in mining areas than elsewhere.

The "demand mechanism" highlighted that mining might attract corrupt officials, again yielding different implications depending on whether mining is similar or more conducive to corruption opportunities than other activities. We employ a variable capturing whether the Afrobarometer interviewer observed police in the PSU. Since the mechanism may operate at higher levels than individual officers, we also test whether he/she identified a police station. For validation purposes, we note that observed police stations and (particularly) police officials systematically correlate with reported police bribes.

Independent of taking the mining-specific or general growth perspective, police should expectedly be spotted more often in mining areas. Indeed, active is positive and with $t=1.8$ for officers and stations (Appendix Table A.58). Nonetheless, mine location is likely endogenous to pre-existing local institutions, and there is no evidence that mine openings induce an influx of police. Controlling for these measures does not systematically reduce the effect of mine opening on police bribes either. This suggests that while mine openings do 
not attract officials, they induce those present to take more bribes, further supporting the supply-side mechanism.

Nonetheless, we outlined more specific expectations for the general- and mining-specific demand-side mechanism(s). Testing these, we find no evidence supporting the general one. Whereas mining increases local economic activity, there is no relationship between activity and police officials or stations. The mining-specific explanation highlighted that mining could entice corrupt officials more than other activities. Whereas mine openings are uncorrelated with police presence, officials might only migrate to mining areas with high activity (and more resources available for bribes). Indeed, nighttime light and police official presence correlate positively in mining areas, and negatively in non-mining areas (Appendix Table A.59). Still, the former relationship does not pass conventional levels of significance $(t=1.5)$, and this differential pattern is absent for police stations.

In sum, we do not find that mining increases corruption simply by boosting economic activity, or clear evidence that mining acts as a "honey-pot" in attracting new officials. However, increased economic activity has a significantly stronger relationship with bribes in mining areas. Further, mine openings induce more police bribes even when holding police presence constant. Taken together, this suggests that the mining-specific supply mechanism contributes to explain why mining increases corruption. Given the available data, we cannot

identify exactly what characteristics of mining strengthen the incentives and capabilities of officials to demand more bribes. Nonetheless, our results suggest that mining is a "curse" to local institutions due to its industry-specific characteristics.

\section{Conclusion}

There is still no consensus concerning whether natural resource extraction increases corruption. The literature contains numerous cross-country regression studies, but they face well-known endogeneity issues. Recent responses to these issues - such as country-fixed ef- 
fects models - have problems of their own, notably little within-country variation in resource variables, making it difficult to identify effects. We therefore shift focus from macro- to microdata, better enabling us to establish causal links. We connect 496 mines in Africa to 92,762 Afrobarometer respondents. This allows dealing with endogeneity concerns - due, for example, to companies' incentives to avoid highly corrupt areas when locating mines - and control for country-specific effects, while preserving variation through the opening of single mines. Using a difference-in-differences strategy, we find that mine openings clearly increase bribe payments.

The paper thus makes two contributions. First, it provides new evidence of the muchdebated causal link between natural resources and corruption. Second, it adds to literatures on local effects of mining and determinants of local-level institutions. While several contributions have recently studied these phenomena, we are the first to systematically study how mining and local-level institutions relate over such an extended geographical area.

Our design and results open up different avenues of future research. Mining may affect other local institutional characteristics; arguments on how mining affects local bureaucratic capacity or political participation could be investigated with resembling designs. Furthermore, the long-run effect of mining on local-level economic development remains unclear. While we find that mining boosts short-term economic activity, the negative long-term consequences of corruption and poor governance are widely assumed. The ability to reap economic-development benefits from resource extraction is supposedly also contingent on having a "high-quality" institutional environment (e.g., Mehlum, Moene and Torvik, 2006), and we show that mining hampers local-level institutional quality. Taken together, local economies might indirectly suffer from mining activities in the longer run, despite the shortterm boost. Whether there is, on net, a (long-term) local "economic resource curse" is an important question for future studies. 


\section{References}

Acemoglu, Daron, Tristan Reed and James A. Robinson. 2014. "Chiefs: Economic Development and Elite Control of Civil Society in Sierra Leone." Journal of Political Economy $122(2): 319-368$.

Ades, Alberto and Rafael Di Tella. 1999. "Rents, Competition, and Corruption." American Economic Review 89(4):982-993.

Afrobarometer Data. N.d. Round 2-5, 2002, 2003, 2004, 2005, 2006, 2008, 2009, 2011, 2012, 2013.

URL: http://www.afrobarometer.org

Alexeev, Michael and Robert Conrad. 2009. "The Elusive Curse of Oil." Review of Economics and Statistics 91(3):586-598.

Andersen, Jørgen J. and Michael L. Ross. 2014. "The Big Oil Change: A Closer Look at the Haber-Menaldo Analysis." Comparative Political Studies 47(7):993-1021.

Andersen, Jørgen J. and Silje Aslaksen. 2013. "Oil and political survival." Journal of Development Economics 100(1):89-106.

Aslaksen, Silje. 2010. "Oil and democracy - more than a cross-country correlation?" Journal of Peace Research 47(4):421-431.

Auty, Richard M. 1993. Sustaining Development in Mineral Economies: The Resource Curse Thesis. New York: Oxford University Press.

Auty, Richard M. 2001. "The political economy of resource-driven growth." European Economic Review 45(4-6):839-846. 
Balk, D. L., U. Deichmann, G. Yetman, F. Pozzi, S. I. Hay and A. Nelson. 2006. "Determining Global Population Distribution: Methods, Applications and Data." Advances in Parasitology 62:119-156.

Beck, Nathaniel and Jonathan N. Katz. 2001. "Throwing out the Baby with the Bath Water: A Comment on Green, Kim, and Yoon." International Organization 2(2):487-495.

Bellows, John and Edward Miguel. 2006. "War and Institutions: New Evidence from Sierra Leone." The American Economic Review 96(2):394-399.

Bellows, John and Edward Miguel. 2009. "War and local collective action in Sierra Leone." Journal of Public Economics 93(11-12):1144 - 1157.

Berman, Nicolas, Mathieu Couttenier, Dominic Rohner and Mathias Thoenig. 2014. "This Mine is Mine! How minerals fuel conflicts in Africa." OxCarre Research Paper 141. URL: http://www.oxcarre.ox.ac.uk/files/OxCarreRP2014141.pdf

Bhattacharyya, Sambit and Roland Hodler. 2010. "Natural resources, democracy and corruption." European Economic Review 54(4):608-621.

Blonigen, Bruce A. 2005. "A Review of the Empirical Literature on FDI Determinants." Atlantic Economic Journal 33(4):383-403.

Boix, Carles. 2003. Democracy and Redistribution. Cambridge: Cambridge University Press.

Brunnschweiler, Christa N. 2008. "Cursing the blessings? Natural resource abundance, institutions and economic growth." World Development 36(3):399-419.

Brunnschweiler, Christa N. and Erwin H. Bulte. 2008. "The resource curse revisited and revised: a tale of paradoxes and red herrings." Journal of Environmental Economics and Management 55(3):248-264. 
Bueno de Mesquita, Bruce and Alastair Smith. 2009. "Political Survival and Endogenous Institutional Change." Comparative Political Studies 42(2):167-197.

Buhaug, Halvard and Jan K. Rød. 2006. "Local Determinants of African Civil Wars, 19702001." Political Geography 25(3):315-335.

Busse, Matthias and Steffen Gröning. 2013. "The resource curse revisited: governance and natural resources." Public Choice 154(1-2):1-20.

Corrigan, Caitlin C. 2014. "Breaking the resource curse: Transparency in the natural resource sector and the extractive industries transparency initiative." Resources Policy 40(June):17-30.

Cuaresma, Jesus C., Harald Oberhofer and Paul A. Raschky. 2011. "Oil and the duration of dictatorships." Public Choice 148(3-4):505-530.

de la Sierra, Raul Sanchez. 2014. "On the Origin of States: Stationary Bandits and Taxation in Eastern Congo." HICN Working Paper 194.

URL: http://www.hicn.org/wordpress/wp-content/uploads/2012/06/HiCN-WP-194.pdf

Deconinck, Koen and Marijke Verpoorten. 2013. "Narrow and scientific replication of "The slave trade and the origins of mistrust in Africa." Journal of Applied Econometrics 28(1):166-169.

Dube, Oeindrila and Juan F. Vargas. 2013. "Commodity Price Shocks and Civil Conflict: Evidence from Colombia." The Review of Economic Studies 80(4):1384-1421.

Esteves, A.M. 2008. "Mining and social development: Refocusing community investment using multi-criteria decision analysis." Resources Policy 33(1):39 - 47.

Fisman, Raymond and Edward Miguel. 2006. "Cultures of corruption: evidence from diplomatic parking tickets.". 
Frankel, Jeffrey A. 2010. "The Natural Resource Curse: A Survey." NBER Working Paper No 15836.

Goldberg, Ellis, Erik Wibbels and Eric Mvukiyehe. 2008. "Lessons from Strange Cases: Democracy, Development, and the Resource Curse in the U.S. States." Comparative Political Studies 41(4-5):477-514.

Haber, Stephen and Victor Menaldo. 2011. "Do Natural Resources Fuel Authoritarianism? A Reappraisal of the Resource Curse." American Political Science Review 105(1):1-26.

Hausmann, Ricardo and Roberto Rigobon. 2003. An Alternative Interpretation of the Resource Curse: Theory and Policy Implications. In Fiscal Policy Formulation and Implementation in Oil-Producing Countries. Washington D.C.: IMF.

Henderson, J. Vernon, Adam Storeygard and David N. Weil. 2012. "Measuring Economic Growth from Outer Space." American Economic Review 102(2):994-1028.

Holmberg, Sören, Bo Rothstein and Nagmeh Nasiritousi. 2009. "Quality of Government: What You Get." Annual review of Political Science 12:135-161.

Human Rights Watch. 2009. Diamonds in the Rough: Human Rights Abuses in the Marange Diamond Fields. Report Human Rights Watch.

Humphreys, Macartan. 2005. "Natural Resources, Conflict, and Conflict Resolution: Uncovering the Mechanisms." Journal of Conflict Resolution 49(4):538-562.

Humphreys, Macartan, Jeffrey D. Sachs and Joseph E. Stiglitz, eds. 2007. Escaping the Resource Curse. New York: Columbia University Press.

Imai, Kosuke, Luke Keele, Dustin Tingley and Teppei Yamamoto. 2011. "Unpacking the Black Box of Causality: Learning about Causal Mechanisms from Experimental and Observational Studies." American Political Science Review 105:765-789. 
Isham, Jonathan, Michael Woolcock, Lant Pritchett and Gwen Busby. 2005. "The varieties of resource experience: Natural resource export structures and the political economy of growth." World Bank Economic Review 19(2):141-174.

Karl, Terry. 1997. The Paraodox of Plenty: Oil Booms and Petro States. Berkeley: University of California Press.

Kotsadam, Andreas and Anja Tolonen. 2013. "Mineral Mining and Female Employment." OxCarre Research Paper 114.

URL: http://www.oxcarre.ox.ac.uk/files/OxCarreRP2013114.pdf

Leite, Carlos and Jens Weidmann. 1999. "Does Mother Nature Corrupt? Natural Resources, Corruption, and Economic Growth." IMF Working Paper 99/85.

URL: http://www.imf.org/external/pubs/ft/wp/1999/wp9985.pdf

Linke, Andrew M. 2013. "The aftermath of an election crisis: Kenyan attitudes and the influence of individual-level and locality violence." Political Geography 37:5 - 17.

Lujala, Paivi. 2009. "Deadly combat over natural resources gems, petroleum, drugs, and the severity of armed civil conflict." Journal of Conflict Resolution 53(1):50-71.

Lujala, Paivi. 2010. "The Spoils of Nature: Armed Conflict and Rebel Access to Natural Resources." Journal of Peace Research 47(1):15-29.

Mauro, Paolo. 1995. "Corruption and Growth." The Quarterly Journal of Economics 110(3):681-712.

Maystadt, Jean-François, Giacomo De Luca, Petros G Sekeris and John Ulimwengu. 2014. "Mineral resources and conflicts in DRC: a case of ecological fallacy?" Oxford Economic Papers 66(3):721-749. 
Mehlum, Halvor, Kalle Moene and Ragnar Torvik. 2006. "Institutions and the resource curse." The Economic Journal 116(1):1-20.

Meredith, Martin. 2006. The State of Africa - A History of Fifty Years of Independence. London: The Free Press.

North, Douglass C. 1990. Institutions, Institutional Change and Economic Performance. Cambridge: Cambridge University Press.

Nunn, Nathan and Diego Puga. 2012. "Ruggedness: The blessing of bad geography in Africa." Review of Economics and Statistics 94(1):20-36.

Nunn, Nathan and Leonard Wantchekon. 2011. "The Slave Trade and the Origins of Mistrust in Africa." American Economic Review 101(7):3221-3252.

Olken, Benjamin A. 2009. "Corruption perceptions vs. corruption reality." Journal of Public economics 93(7):950-964.

Oster, Emily. 2013. "Unobservable selection and coefficient stability: Theory and validation.".

Prebisch, Raul. 1950. The Economic Development of Latin America and Its Principal Problems. New York: United Nations Department of Economic Affairs.

Rock, Michael. 2009. "Corruption and Democracy." The Journal of Development Studies $45(1): 55-75$.

Rohner, Dominic, Mathias Thoenig and Fabrizio Zilibotti. 2013. "Seeds of distrust: conflict in Uganda." Journal of Economic Growth 18(3):217-252.

Ross, Michael L. 2001. "Does Oil Hinder Democracy." World Politics 53(3):325 -61. 
Ross, Michael L. 2004a. "How Does Natural Resource Wealth Influence Civil War? Evidence from 13 Cases." International Organization 58(1):35-67.

Ross, Michael L. 2004b. "What Do We Know About Natural Resources and Civil War." Journal of Peace Research 41(3):337-356.

Ross, Michael L. 2012. The Oil Curse: How Petroleum Wealth Shapes the Development of Nations. Princeton: Princeton University Press.

Sachs, Jeffrey D. and Andrew M. Warner. 1995. "Natural resource abundance and economic growth." NBER Working Paper No. 5398.

URL: http://www.nber.org/papers/w5398

Serra, Danila. 2006. "Empirical determinants of corruption: A sensitivity analysis." Public Choice 126(1-2):225-256.

Shleifer, Andrei and Robert W. Vishny. 1993. "Corruption." Quarterly Journal of Economics 108(3):599-617.

Smith, Benjamin. 2004. "Oil Wealth and Regime Survival in the Developing World, 19601999." American Journal of Political Science 48(2):232-246.

Smith, Benjamin. 2006. "The Wrong Kind of Crisis: Why Oil Booms and Busts Rarely Lead to Authoritarian Breakdown." Studies in Comparative International Development $40(4): 55-76$.

SNL Metals and Mining. 2014. "Raw Materials Database.".

Stijns, Jean-Philippe C. 2005. "Natural resource abundance and economic growth revisited." Resources Policy 30(2):107-130. 
Svensson, Jakob. 2005. "Eight Questions about Corruption." Journal of Economic Perspectives 19(3):19-42.

Tolonen, Anja. 2014. "Local Industrial Shocks, Female Empowerment and Infant Health: Evidence from Africas Gold Mining Industry." University of Gothenburg: Job Market Paper.

URL: https : //anjatolonen.files.wordpress.com/2012/08/tolonen_jmp_jan2015.pdf

Treisman, Daniel. 2000. "The causes of corruption: a cross-national study." Journal of Public Economics 76(3):399-457.

Van Rijkgehem, Caroline and Beatrice Weder. 2001. "Bureaucratic corruption and the rate of temptation: do wages in the civil service affect corruption, and by how much?" Journal of Development Economics 65(2):307-331.

Vicente, Pedro C. 2010. "Does oil corrupt? Evidence from a natural experiment in West Africa." Journal of Development Economics 92(1):28-38. 